\title{
The Investigation of Antimicrobial Activities and Hypoglycemic Effect of Sumac (Rhus coriaria L.) Syrups in Different Region
}

\author{
Sevim ÇİFTÇİ YEGİN*, Duygu ODABAŞ ALVER \\ Giresun University, Health Service Vocational School of Higher Education, Giresun, Turkey \\ (ORCID: 0000-0003-3950-4399) (ORCID: 0000-0002-3133-3495)
}

\begin{abstract}
This study aimed to determine the antimicrobial activity and hypoglycemic effect of sumac sours collected from different regions. Rhus coriaria, is the only species of rhus in Turkey. It shows spread in different regions in Turkey. Particularly, it is used as sour in Anatolia. Sumac sour is usually consumed in south provinces in Turkey. In the study, three Gram (-), three Gram (+) and 1 yeast strains obtained from the culture collection of the Microbiology Laboratory of Ordu University were used. The antimicrobial effects of samples were investigated by using agar disc diffusion method. Hypoglycemic effect was investigated with $\alpha$-amylase and $\alpha$-glucosidase inhibition assays. In result of the study, almost all samples formed zones ranging from 31.5 to $6 \mathrm{~mm}$ against bacteria and yeast, but Antep, Hatay sumac syrup samples did not create against Candida albicans and Candida albicans, Staphylococcus aureus, respectively. Consequently, sumac syrups were determined to be an effective antimicrobial activity. In addition, we can say that there are hypoglycemic effects of sumac syrup samples in Mersin, Hatay and Gaziantep respectively.
\end{abstract}

Keywords: Antimicrobial activity, Hypoglycemic effect, Sumac syrup.

\section{Farklı Yörelere Ait Sumak Ekşilerinin (Rhus coriaria L.) Antimikrobiyal Aktivitesi ve Hipoglisemik Etkisinin Araştırılması}

\begin{abstract}
$\ddot{\mathbf{O} z}$
$\mathrm{Bu}$ çalışmada, farklı yörelere ait sumak ekşilerinin antimikrobiyal aktivitesi ve antidiyabetik etkisinin belirlenmesi amaçlanmıştır. Rhus coriaria, Rhus cinsinin yurdumuzda yetişen tek türüdür. Türkiye' de farklı bölgelerde yayılım göstermektedir. Sumak, ekşilik verici olarak kullanılan bir baharattır. Ülkemizin güney illerinde çoğunlukla tüketilir. Çalışmada Ordu Üniversitesi Biyoloji Bölümü Mikrobiyoloji laboratuvarı kültür koleksiyonundan elde edilen üç Gram (-), üç Gram (+) ve bir maya suşu kullanılmıştır. Agar disk difüzyon metodu ile örneklerin antimikrobiyal aktivitesi incelenmiştir. $\alpha$-amilaz ve $\alpha$-glikozidaz inhibisyonunun ölçülmesi ile hipoglisemik etkisi belirlenmiştir. Çalışmamızda hemen hemen tüm örneklerin bakteriler ve mayaya karşı 31,5 ile $6 \mathrm{~mm}$ arasında değişen zonlar oluşturduğu gözlenmiş̧ir. Antep örneği Candida albicans ve Hatay örneği Candida albicans ile Staphylococcus aureus'a karşı zon oluşturmamıştır. Sonuç olarak, sumak ekşisinin etkili bir antimikrobiyal aktiviteye sahip olduğunu söyleyebiliriz. Ayrıca sumak ekşisi örneklerini Mersin, Hatay, Gaziantep şeklinde sıralayarak hipoglisemik etkisi olduğunu belirtebiliriz.
\end{abstract}

Anahtar kelimeler: Antimikrobiyal aktivite, Hipoglisemik etki, Sumak ekşisi.

\section{Introduction}

Recently, together the awareness of health, the inadequacy against diseases and the detection of side effects of drugs increased the demand for the use of natural products. When wild plants are evaluated in terms of medicine, it is seen that these herbs are the raw materials of many drugs used for human and animal health [1].

"Corresponding author: sevimbio@gmail.com

Received: 27.06.2019, Accepted: 18.10.2019 
Rhus coriaria L. (Anacardiaceae), known as locally name Sumac, is collected in the autumn months. It is used in powder form or boiled with a certain amount of water. There are different two types as berries and leaves of plant [2]. Rhus coriaria is the only species of the Rhus that grows in our country. In our country, its distributed Mediterranean, Aegean, Southeastern Anatolia, North Anatolia, Thrace and Central Anatolia regions [3]. Many plants were investigated in terms of microbiological, pharmacological and plant defense mechanisms [4]. Resistance to antibiotics of microorganisms and the discovery of new pathogenic microorganisms were led to investigate the antimicrobial properties of medicinal plants [5].

$\alpha$-amylase is the main enzyme that is responsible for the breakdown of starch to more simple sugars [6,7]. Although the activity of the enzyme has not been directly involved in the etiology of diabetes, $\alpha$-amylase inhibitors have known to improve glucose tolerance in diabetic patients [8].

In recent years, diabetes is a disease that is commonly seen and reduces the quality of life of patients. Studies on plants traditionally used among the people are carried out continuously. Particularly, it's are carried out different studies of the plants used against diabetes $[9,10]$. The aim of the study is state antimicrobial activity and hypoglycemic effect of sumac syrups.

\section{Material and Method}

As a material; Hatay, Gaziantep and Mersin sumac sours are bought in local markets commercially.

\subsection{Antimicrobial Activity}

Microorganisms were obtained from the cultures of Microbiology Laboratory of Ordu University Biology Department. Three Gram (+) bacterial strains (Bacillus cereus, Clostridium perfringen, Staphylococcus aureus), three Gram (-) bacterial strains (Pseudomonas aeruginosa, Escherichia coli, Klebsiella pneumonia) and a yeast strain (Candida albicans) were used for the determination of antimicrobial activity.

In the study, The Agar Disc Diffusion Method was used. In this technique, a suitable trough with the test organism is used with a trough system in which the substance to be tested is located. At the end of the incubation period, if the substance is effective, inhibition zones are formed around the pits without significant growth. Formed the diameters of the inhibition zones are measured and evaluated $[11,12]$.

\subsection{Hypoglycemic Effect}

\subsubsection{Assay of $\alpha$-amylase inhibition}

$\alpha$-amylase inhibition (in vitro) was analyzed according to the method of Bernfeld with minor modifications $[13,14]$. The $\% 0.5$ starch solution was made by boiling and blending $0,25 \mathrm{~g}$ potato starch into $50 \mathrm{~mL}$ deionized water for $15 \mathrm{~min}$. The $\alpha$-amylase (EC 3.2.1.1) $0,5 \mathrm{unit} / \mathrm{mL}$ enzyme solution was prepared by blending $\alpha$-amylase in phosphate buffer solution including 6,7 $\mathrm{mM} \mathrm{NaCl}$. Samples (5-100 $\mu \mathrm{g} / \mathrm{mL}$ ) and acarbose were dissolved at various concentrations in phosphate buffer solution. The color reagent was a solution including $20 \mathrm{~mL}-96 \mathrm{mM}$ DNS (Dinitrosalicylic acit), $8 \mathrm{~mL}-5,31 \mathrm{M}$ sodium potassium tartrate in $2 \mathrm{M} \mathrm{NaOH}$ and $12 \mathrm{~mL}$ deionized water. $1 \mathrm{~mL}$ of samples or acarbose and $1 \mathrm{~mL}$ enzyme solution were waited at $25^{\circ} \mathrm{C}$ for $30^{\prime}$ by mixed. The $1 \mathrm{~mL}$ mix was supplemented to $1 \mathrm{~mL}$ starch solution. It's waited at $25^{\circ} \mathrm{C}$ for $3^{\prime}$. After, the $1 \mathrm{~mL}$ color reagent was supplemented. Sample tubes were waited in $85^{\circ} \mathrm{C}$ water bath for $15^{\prime}$. After, the reaction mix was diluted with $9 \mathrm{~mL}$ distilled water. Absorbance of the mix was recorded at $540 \mathrm{~nm}$ using spectrophotometer and $\alpha$-amylase inhibition activities were expressed as $\mathrm{IC}_{50}$ (Inhibition concentration \%50). The $\mathrm{IC}_{50}$ values were determined by linear regression analysis using four different concentrations in three times and represent mean of the data. Blanks were prepared. After, the color reagent was supplemented to starch solution and incubated into the water bath. Acarbose solution was used as positive control. 


\subsubsection{Assay of $\alpha$-glucosidase inhibition}

A previously described bioassay method was used for measurement $\alpha$-glucosidase inhibition of samples [15]. The enzyme solution is contained $20 \mu \mathrm{L}-0,5 \mathrm{U} / \mathrm{mL} \alpha$-glucosidase (EC 3.2.1.20) $(20-0,5 \mathrm{unit} / \mathrm{mL})$ and $120 \mu \mathrm{L}-0,1 \mathrm{M}-\mathrm{pH}$ 6,9 PBS (Phosphate buffered saline). Samples and acarbose were dissolved at different concentrations in PBS, were stirred with enzyme solution and waited during $15^{\prime}$ at $37^{\circ} \mathrm{C}$. The reaction was stoped by supplementing $80 \mu \mathrm{L}, 0,2 \mathrm{M} \mathrm{NaCO}_{3}$ solution. The absorbance was measured at $405 \mathrm{~nm}$ in spectrophotometer. The $\mathrm{IC}_{50}$ values of samples for the $\alpha$-glucosidase inhibition activities were determined by linear regression analysis using four different concentrations in three times and represent mean of the data.

\section{Results and Discussion}

As you can see in Table 1, sumac syrup samples demonstrated generally antimicrobial activity against the used bacteria except for Candida albicans and Staphylococcus aureus. While Hatay and Antep sumac syrup samples show no activity against Candida albicans, only Hatay sample has no effect against Staphylococcus aureus.

Table 1. Inhibition zone diameters ( $\mathrm{mm}$ ) of samples against bacteria and yeast

\begin{tabular}{lccc}
\hline & $\begin{array}{c}\text { Gaziantep Sumac } \\
\text { Syrup } \\
(\mathbf{m m})\end{array}$ & $\begin{array}{c}\text { Hatay Sumac Syrup } \\
(\mathbf{m m})\end{array}$ & $\begin{array}{c}\text { Mersin Sumac Syrup } \\
(\mathbf{m m})\end{array}$ \\
\hline Bacillus cereus & 12.5 & 7 & 12 \\
Clostridium perfringens & 17 & 7 & 10 \\
Staphylococcus aureus & 21 & - & 14 \\
Pseudomonas aeruginosa & 28 & 6 & 15 \\
Klebsiella pneumoniae & 20 & 10 & 12 \\
Escherichia coli & 31.5 & 11 & 11.6 \\
Candida albicans & - & - & 8 \\
\hline
\end{tabular}

In table 2 shows that, sumac syrup samples showed lower $\alpha$-glucosidase inhibition and $\alpha$ amylase inhibition in comparison with acarbose $(\mathrm{p}<0.05)$. Hatay and Mersin sumac syrup samples were demonstrated six and four times lower $\alpha$-amylase inhibition activity than acarbose, respectively. Acarbose, an alpha-glucosidase inhibitor, is a group of drugs by slow the degradation of carbohydrates from the intestine and prevent the rapid rise of blood sugar after meal.

Table 2. Hypoglycemic effects $\left(\mathrm{IC}_{50} 0^{-\mu \mathrm{g} \mathrm{mL}}{ }^{-1}\right.$ ) of Sumac Syrup Samples and Acarbose

\begin{tabular}{|c|c|c|c|c|}
\hline & $\begin{array}{c}\text { Gaziantep Sumac } \\
\text { Syrup }\end{array}$ & $\begin{array}{c}\text { Hatay Sumac } \\
\text { Syrup }\end{array}$ & $\begin{array}{l}\text { Mersin Sumac } \\
\text { Syrup }\end{array}$ & Acarbose \\
\hline $\begin{array}{ll}\text { a-Glucosidase } & \text { Inhibition } \\
\left(\mathrm{IC}_{50^{-}} \mu \mathrm{g} \mathrm{mL}^{-1}\right) & \end{array}$ & 2620.75 & 2048.15 & 1090.55 & 79.12 \\
\hline $\begin{array}{l}\alpha \text {-Amylase Inhibition } \\
\left(\mathrm{IC}_{50^{-}} \mu \mathrm{g} \mathrm{mL}^{-1}\right)\end{array}$ & 1329.29 & 576 & 377.9 & 94.89 \\
\hline
\end{tabular}

Sumac as species is commonly used in the country. It is known many benefits of sumac as to be useful used in the treatment of anorexia, indigestion, diarrhoea, hyperglycaemia and haemorrhage [16].

Digrak et al. [17] determined antibacterial and antifungal activity of some medicinal plants including Rhus coriaria in Turkey. Antimicrobial activity was tested by disc diffusion method using Bacillus brevis FMC 3, Bacillus cereus FMC 19, Bacillus subtilis IMG 22, Bacillus megaterium DSM 32, Escherichia coli DM, Pseudomonas aeruginosa DSM 50071, Enterobacter aerogenes CCM 2531, Listeria monocytogenes Scott A, Staphylococcus aureus Cowan 1 and Micrococcus luteus LA 2971, Candida albicans CCM 314, Candida tropicalis, Rhus coriaria showed 35-51 mm inhibition zones against bacteria in all trials [14]. Results obtained from this study are consistent with the literature (Table $1)$. 
In another study, antibacterial properties of sumac samples with different maturity were examined. In general, Bacillus bacteria are more sensitive. It has shown Gram (-) bacteria greater inhibition zone than Gram (+) bacteria. Moreover, it showed that the antibacterial effect according to their degree of maturity did not change, but there was directly proportional increase to sumac concentrations [18].

Ibrahim and El-Shehawy [16] investigated the antimicrobial content of sumac extracts. St. aureus, $B$. subtilus, S. typhimarium, E-coli HMY13 bacteria were used in this study. The zone diameters of two extracts were determined between $12-19 \mathrm{~mm}$ depend on the extract concentration as positive correlation. They found that formed between of $12 \mathrm{~mm}-29 \mathrm{~mm}$ zone diameters increasing as the percentage close to each other in extract of both spices [19].

In another study, Salmonella typhimurium ATCC 13311 in tomato was washed with distilled water, suspensions containing sumac extract and partridge oil for reducing bacteria population. It is compared resistance against nalidixic acid. As a result, it has been suggested that suspensions containing both sumac extract and partridge oil can be used for microbial protection of tomatoes without affecting quality [20].

In one review study, antimicrobial and antioxidant properties of sumac have been reported by many studies $[21,22,23]$.

The researchs on sumac extracts reported desirable bioactivities: antifungal, antimalarial, antifibrogenic, antimicrobial, anti-inflammatory, antioxidant, antimutagenic, antiviral, antitumorigenic, anti-thrombin, cytotoxic, hypoglycemic and leukopenic [24].

In the investigated sumac syrup samples, Mersin Sumac syrup samples have the highest $\alpha$ glucosidase and $\alpha$-amylase inhibition activities. The other results were given in Table 2 . Acarbose used as control in these assays shows the highest $\alpha$-glucosidase and $\alpha$-amylase inhibition activity when compared with the samples (Table 2). The results obtained for acarbose are quite compatible with the literature [14].

According to ethnobotanical studies in the review, plants that the most commonly used between people in patients with gestational diabetes mellitus in diabetes mellitus treatment in Turkey were discussed. There is no information about the use of Sumac in pregnant women in the literature [9].

Karaman and Elgin Ceben stated that sumac is taken part in the hypoglicemic list. Fruits and leaves of sumac are consumed by distillation decoction method [10].

It has already been reported that Rhus coriaria might have hypoglycemic activity by inhibition of $\alpha$-amylase, $\alpha$-glycoside hydrolase [24].

In the Alloxan-induced diabetic rats, administration of the extract of Rhus coriaria fruits produced a statistically significant acute and long-term decrease in postprandial blood glucose concentration [25].

\section{Conclusion and Suggestions}

In this study, sumac syrups belonging to different regions were used and their antimicrobial activities and hypoglisemic effect of sumacs were determined. Sumac spice has gained importance with its hypoglisemic and antimicrobial properties. In the feature, it can be used as an effective natural source with hypoglycemic effect in diabetes mellitus especially Hatay and Mersin sumac syrup. Sumac can be evaluated as hypoglicemic agents according to the literature. Although sumac shrup was used in our study, we obtained effective hypoglisemic and antimicrobial results for sumac shrup as well as sumac powder. Therefore, we can say that consumption of sumac as sumac shrup is important as sumac sour. According to literature, sumac powder was used for determination of biochemical activities of sumac many times but not sumac shrup so this study is important to be the first as using sumac shrup. In the light of literature, in vivo studies related to sumac shrup can be studied and current usage areas can be supported.

\section{Author's Contributions}

Biochemical analysis of the study was done by Dr. Sevim ÇİFTÇİ YEGIN and microbiological analysis by Duygu ODABAŞ ALVER. 


\section{Statement of Conflicts of Interest}

No potential conflict of interest was reported by the authors.

\section{Statement of Research and Publication Ethics}

The author declares that this study complies with Research and Publication Ethics. None of the experiments involved sacrificing animals and, therefore, we did not require a specific approval from any institutional animal and human research ethics committee.

\section{References}

[1] Kırbağ S., Zengin F. 2006. Elazığ Yöresindeki Bazı Tıbbi Bitkilerin Antimikrobiyal Aktiviteleri. Journal of Agriculturel Science, 16 (2): 77-80.

[2] Yücel E., Tapırdamaz A., Yücel Şengül İ., Yılmaz G., Ak A. 2011. Determining the Usage Ways and Nutrient Contents of Some Wild Plants Around Kisecik Town (Karaman/Turkey). Biological Diversity and Conservation, 4 (3): 71-82.

[3] Koyuncu M., Köroğlu A. 1991. Rhus coriaria Yaprak ve Meyvelerinin Anatomik İncelenmesi. Doğa-Tr Journal of Pharmacy, 1: 89-96.

[4] Kırbağ S., Bağcı E. 2000. Piceae abies (L.) Karst.ve Picea orientalis (L.) Link Uçucu Yağlarının Antimikrobiyal Aktivitesi Üzerine Bir Araştırma. Journal of Quafqaz University, 3 (1): 183-190.

[5] Naz S., Siddiqi R., Ahmad S., Rasool S.A., Sayeed S.A. 2007. Antibacterial Activity Directed Isolation of Compounds from Punica granatum. Journal of Food Sciences, 72: 341-345.

[6] Alexander R.J. 1992. Maltodextrins: Production, Propertiesand Applications. Starch Hydrolysis Products in Worldwide Technology, Production and Applications, Edited by Schenck FW, Hebeda RE, New York: VHC Publishers, 233-276.

[7] Davies G.J., Henrissat B. 1995. Structures and Mechanisms of Glycosyl Hydrolases. Structure, 3 (9): 853-859.

[8] Lebovit H.1998. $\alpha$-Glucosidase Inhibitors as Agents in the Treatment of Diabetes. Diabetes Reviewer, 6: 132-145.

[9] Durmuş R.N., Şahin E., Bireller S. 2016. Gestasyonel Diyabette Hipoglisemik Etkili Bitkilerin Kullanımı. Deneysel Tıp Araştırma Enstitüsü Dergisi, 6 (11): 3-16.

[10] Karaman Ö., Elgin Cebe G. 2016. Diyabet ve Türkiye'de Antidiyabetik Olarak Kullanılan Bitkiler. Journal of Faculty of Pharmacy of Ankara University, 40 (3): 47-61.

[11] Dorman H.J.D., Deans S.G. 2000. Antimicrobial Agents From Plants Antibacterial Activitiy of Plant Volatile Oils. Journal of Applied Microbiology, 88: 308-316.

[12] Koneman E.W., Allen S.D., Janda W.M., Schreckenberger P.C., Winn W.C. 1997. Color Atlas and Textbook of Diagnostic Microbiology. Lippincott-Raven Pub, 536p. Edinburg.

[13] Bernfeld P. 1955. Methods in Enzymology, Academic Press, 263p. New York.

[14] Güder A. 2016. Influence of Total Anthocyanins from Bitter Melon (Momordica charantia Linn.) as Antidiabetic and Radical Scavenging Agents. Iran Journal of Pharmaceutical Research, 15 (1): 301-309.

[15] McCue P., Kwon Y.I., Shetty K. 2005. Anti-Amylase, Anti-Glucosidase and Anti-Angiotensin IConverting Enzyme Potential of Selected Foods. Journal of Food Biochemistry, 29: 278-294.

[16] Wtherilt H., Pala M. 1994. Spices, Herbs and Edible Fungi. Developments in Food Science, 34: 285-307.

[17] Dığrak M., Alma M.H., Ilçim A. 2001. Antibacterial and antifungal activities of Turkish medicinal plants. Pharmaceutical Biology, 39 (5): 346-350.

[18] Nasar-Abbas S.M., Kadir Halkman A. 2004. Antimicrobial Effect of Water Extract of Sumac (Rhus coriaria L.) on the Growth of Some Food Borne Bacteria Including Pathogens. International Journal of Food Microbiology, 97: 63-69. 
[19] Ibrahim F.Y., El-Shehawy S.M. 2013. The Antimicrobial and Antioxidant Effects of Aquous Thyme and Sumac Extracts in Refregirated Minced Beef Meat. International Journal of Product Development, 18 (1): 23-35.

[20] Tiryaki Gündüz G., Aktuğ Gönül Ş., Karapinar M. 2010. Efficacy of Sumac and Oregano in the Inactivation of Salmonella Typhimurium on Tomatoes. International Journal of Food Microbiology, 141: 39-44.

[21] Durmuş D., Türer C.Ç. 2018. Effects of Polyphenolic Compounds from Phytochemicals on Periodontium. Journal of Biotechnology and Strategic Health Research, 2 (3): 138-145.

[22] Ünver A., Özcan M.M. 2010. Fatty Acid Composition of Seed and Pericarp of Sumach (Rhus coriaria L.) Grown Wild in Different Regions of Turkey. Journal of Food, Agriculture \& Environment, 8 (1): 31-33.

[23] Rayne S., Mazza G. 2007. Biological Activities of Extracts from Sumac (Rhus spp.): A review. Plant Foods for Human Nutrition, 62 (4): 165-75.

[24] Giancarlo S., Rosa L.M., Nadjafi F., Francesco M. 2006. Hypoglycaemic Activity of Two Spices Extracts: Rhus coriaria L. and Bunium persicum Boiss. Natural Product Research, 20: 882-886.

[25] Mohammadi S., Montasser Kouhsari S., Monavar Feshani A. 2010. Antidiabetic Properties of the Ethanolic Extract of Rhus coriaria Fruits in Rats. DARU Journal of Pharmaceutical Sciences, 18 (4): 270-275. 